\title{
Boron and Strontium Isotopic Characterization of Coal Combustion Residuals: Validation of New Environmental Tracers
}

\author{
Laura S. Ruhl, ${ }^{* \dagger}$ Gary S. Dwyer, ${ }^{\ddagger}$ Heileen Hsu-Kim, ${ }^{\S}$ James C. Hower, ${ }^{\prime \prime}$ and Avner Vengosh ${ }^{\ddagger}$ \\ ${ }^{\dagger}$ University of Arkansas at Little Rock, Little Rock, Arkansas 72204, United States \\ ${ }^{\ddagger}$ Division of Earth and Ocean Sciences, Nicholas School of the Environment, Duke University, Durham, North Carolina 27708, \\ United States \\ ${ }^{\S}$ Civil and Environmental Engineering, Pratt Engineering School, Duke University, Durham, North Carolina 27708, United States \\ "University of Kentucky Center for Applied Energy Research, 2540 Research Park Dr., Lexington, Kentucky 40511, United States
}

Supporting Information

ABSTRACT: In the U.S., coal fired power plants produce over 136 million tons of coal combustion residuals (CCRs) annually. CCRs are enriched in toxic elements, and their leachates can have significant impacts on water quality. Here we report the boron and strontium isotopic ratios of leaching experiments on CCRs from a variety of coal sources (Appalachian, Illinois, and Powder River Basins). CCR leachates had a mostly negative $\delta^{11} \mathrm{~B}$, ranging from -17.6 to $+6.3 \%$, and ${ }^{87} \mathrm{Sr} /{ }^{86} \mathrm{Sr}$ ranging from 0.70975 to 0.71251 . Additionally, we utilized these isotopic ratios for tracing CCR contaminants in different environments: (1) the 2008 Tennessee Valley Authority (TVA) coal ash spill affected waters; (2) CCR effluents from power plants in Tennessee and North Carolina; (3) lakes and rivers affected by CCR effluents in North Carolina; and (4) porewater extracted from sediments in lakes affected by CCRs. The boron isotopes measured in these environments had a distinctive negative $\delta^{11} \mathrm{~B}$

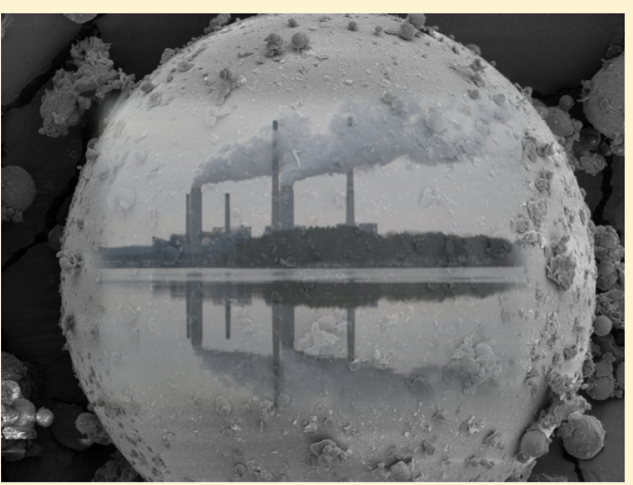
signature relative to background waters. In contrast ${ }^{87} \mathrm{Sr} /{ }^{86} \mathrm{Sr}$ ratios in CCRs were not always exclusively different from background, limiting their use as a CCR tracer. This investigation demonstrates the validity of the combined geochemical and isotopic approach as a unique and practical identification method for delineating and evaluating the environmental impact of CCRs.

\section{INTRODUCTION}

Coal fired power plants are ubiquitous in the United States and many countries around the world providing affordable electricity to consumers. In the U.S., coal generated 39\% of the electricity in 2013. ${ }^{1}$ Approximately six hundred power plants $^{2}$ generate 136 million tons of coal combustion residuals (CCRs) annually, of which $56 \%$ is stored in surface impoundments and landfills. ${ }^{3}$ The remaining CCRs are reused for concrete, cement, and other applications in the construction industries. ${ }^{4}$ CCRs encompass fly ash, bottom ash, boiler slag, and flue gas desulfurization (FGD) products and are typically enriched in toxic elements such as $\mathrm{As}, \mathrm{B}, \mathrm{Se}, \mathrm{Hg}$, and $\mathrm{Sr}^{5,6}$ The characteristics of CCRs vary substantially across coal-fired plants and depend on a unique set of circumstances including coal source and processes within the coal plants. ${ }^{7}$ Most coalfired power plants burn a blend of coals depending on sulfur content of the coal, the plant scrubber technology, and the current price of coal. These variations control the type of coal and thus the generated CCRs, which can influence the composition of leachates generated from CCRs in coal-fired plants. ${ }^{8}$ Variations in chemical composition can complicate the ability to identify and track the migration of CCR contaminants in the environment.
CCRs have been shown to have a significant impact on water quality. ${ }^{8,9}$ Therefore, distinguishing CCR effluents from other anthropogenic or naturally occurring contamination sources is of utmost importance. The objectives of this study were to characterize the boron and strontium isotopic signatures in CCRs originated from a variety of coal sources and to understand their potential as environmental tracers. While there is extensive literature on the chemistry of coal, CCRs, and their leachates, ${ }^{10-13}$ only a few studies have addressed the boron and strontium isotopic compositions of CCRs. Williams and Hervig ${ }^{14}$ measured boron isotopic ratios of different coals in the U.S. and found a wide range of negative $\delta^{11} \mathrm{~B}$ values $(-70 \%$ to $-1 \% 0)$. This negative $\delta^{11} \mathrm{~B}$ signature is different from meteoric boron $(10-40 \%$ ), domestic wastewater (0$10 \% 0)$, seawater $(39 \% 0)$, and saltwater intrusion and brines $(>39 \% 0)^{15}$ and thus could provide a unique tool for elucidating CCR effluents compared to the relatively positive $\delta^{11} \mathrm{~B}$ values expected for most uncontaminated water.

\section{Received: July 31, 2014}

Revised: November 23, 2014

Accepted: November 24, 2014

Published: November 24, 2014 


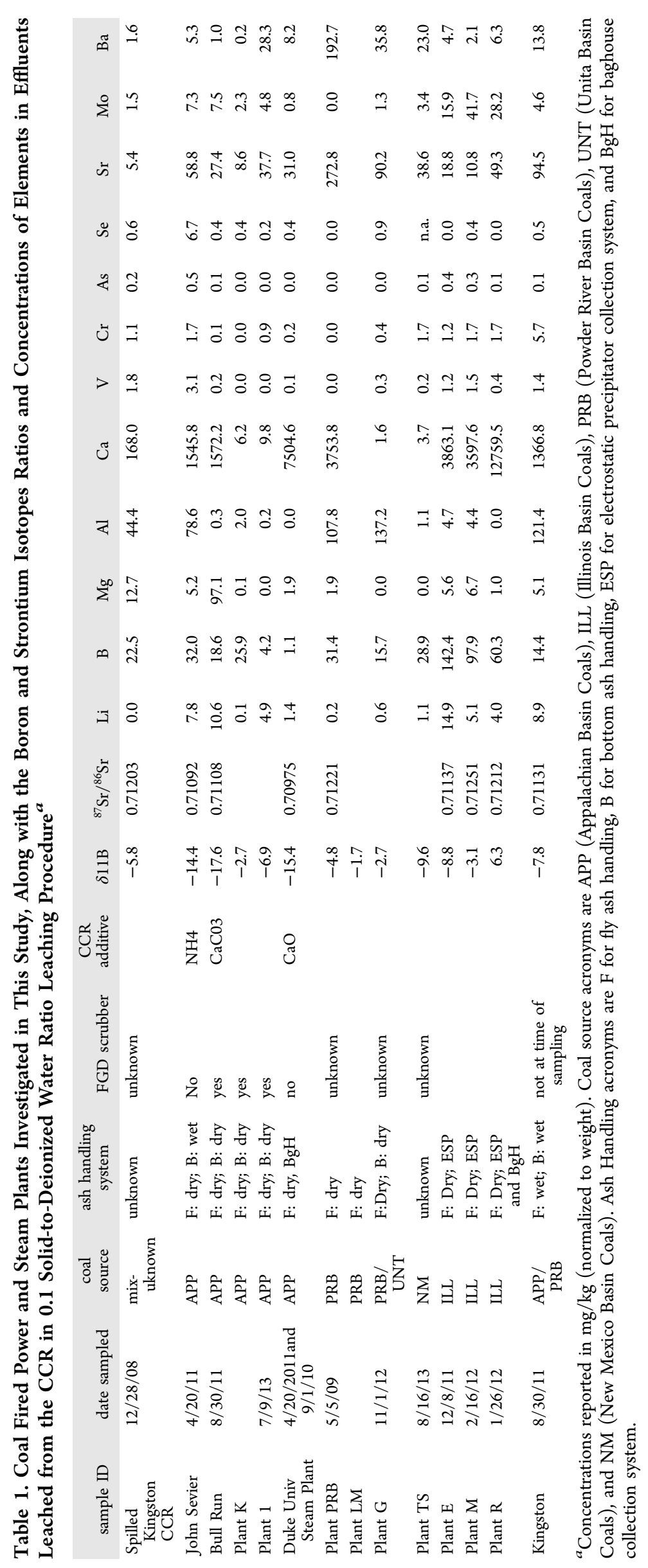


While elevated boron characterizes CCRs, elemental boron cannot exclusively delineate CCRs in the environment because of other potential sources with similar high boron. For example, both domestic wastewater ${ }^{15}$ and oil and gas wastewater ${ }^{16}$ have high boron contents. Consequently, combining elemental boron and isotopic ratios are essential for determining the source of contaminated waters. A recent study by Warner et al. ${ }^{16}$ has shown elevated concentrations of boron (up to 62 ppm) with high $\delta^{11} \mathrm{~B}$ in hydraulic fracturing flowback fluids, demonstrating that elevated boron concentration alone cannot be used as an indicator of CCR contamination. The limited data available on boron isotope ratios in CCRs suggest that coal ash has a similar $\delta^{11} \mathrm{~B}$ value to the coal. Data was reported for a bituminous coal ash, ${ }^{17}$ two unknown sourced fly ashes, ${ }^{18}$ and NIST $1633 \mathrm{a}^{14}$ with negative $\delta^{11} \mathrm{~B}$ values of -4 to $-19 \%$, ${ }^{14,17,18}$ although the direct relationship between the composition of coexisting coal and CCRs has not yet been established. Coal combustion at high temperature volatilizes most of the elements associated with the organic phases (including boron) and volatile elements associated with silicate phases in coal. ${ }^{19}$ Analysis of CCRs ${ }^{14,18}$ indicates that there is no isotopic fractionation associated with the coal combustion process, and CCRs retain the $\delta^{11} \mathrm{~B}$-depleted signature measured in the coal. Boron is associated with the easily leachable fraction of elements $^{20}$ that adsorbed onto the fly ash particles during cooling of exhaust gas. Since there is no species-specific preferential leaching to water (i.e., ${ }^{11} \mathrm{~B}$-enriched boric acid relative to the ${ }^{10} \mathrm{~B}$-depleted tetrahedral boron), no isotopic fractionation is expected during the leaching of boron from CCRs and thus the boron isotopic imprints of contaminated water would mimic the CCR composition.

In addition to boron, we evaluated the strontium isotopic ratios $\left({ }^{87} \mathrm{Sr} /{ }^{86} \mathrm{Sr}\right)$ as an additional tool for tracing CCR effluents. Strontium isotopes are not fractionated during the mobilization and recycling of $\mathrm{Sr}$ in the hydrological system. ${ }^{21}$ Coal beds in Wyoming were analyzed for ${ }^{87} \mathrm{Sr} /{ }^{86} \mathrm{Sr}$ isotopes as a tracer for hydrologic basin movement and showed some heterogeneity in the $\mathrm{Sr}$ ratios, ranging from 0.712 to $0.714{ }^{22}$ Hurst et al. ${ }^{23}$ analyzed coal, fly ash, and bottom ash for ${ }^{87} \mathrm{Sr} /{ }^{86} \mathrm{Sr}$ and found a range of 0.70883 to 0.70972 . Brubaker et al. $^{24}$ performed leaching experiments on Appalachian coal and found an increasing ${ }^{87} \mathrm{Sr} /{ }^{86} \mathrm{Sr}$ ratio with acidic leaching (ranging from 0.7107 to 0.7138 ), indicating that dissolution of different phases in coal results in different $\mathrm{Sr}$ isotopic ratios. Effluent from a fly ash pond in West Virginia that reflected the most soluble fraction, however, had a rather narrow range around $0.7124 .{ }^{24}$ Similar ${ }^{87} \mathrm{Sr} /{ }^{86} \mathrm{Sr}$ ratios were measured in effluents from valley fills that are associated with mountaintop removal coal mining as well as water-leachates from the Appalachian coal in West Virginia. ${ }^{25}$ Each of these analyses was performed on specific coals and CCRs, therefore $\mathrm{Sr}$ isotope ratios could vary in different geological basins and degrees of leaching. Given that the $\mathrm{Sr}$ isotopic composition of coal and CCRs is expected to reflect the local geology and hydrology of the original depositional environment in which coal was deposited, $\mathrm{Sr}$ isotopic variations of CCRs should reflect their original coal source. In fly ash, a minor portion of strontium is potentially leachable due to surface adsorption, but the bulk is associated with the silicate phases and therefore the leaching is relatively slower. ${ }^{24,26}$ Another consideration would be the addition of lime $(\mathrm{CaO})$ or $\mathrm{CaCO}_{3}$ with a different $\mathrm{Sr}$ isotopic ratio in $\mathrm{SO}_{2}$ scrubbers as part of the Flue Gas Desulfurization (FGD) process. Such an addition could have an impact on the $\mathrm{Sr}$ isotopic fingerprints of leachates originated from these CCRs (i.e., $\mathrm{CaCO}_{3}$ typically contains $500-1500 \mathrm{ppm}$ of $\mathrm{Sr}$ ). ${ }^{23,27}$

By developing integrated geochemical and isotopic fingerprints of CCRs, this paper aims to provide the necessary diagnostic tools to elucidate the environmental impact of CCRs, which is one of the increasingly recognized sources of anthropogenic pollution in the US. ${ }^{8}$ The study is based on (1) systematic laboratory leaching experiments of CCRs from 14 coal fired power and steam plants burning an assortment of coals from the Appalachian, Illinois, and Powder River Basins in the U.S. (Table 1); and (2) field environmental sampling of waters receiving CCR effluents, including (a) surface and porewater in a river system affected by the 2008 TVA coal ash spill in Kingston, TN; (b) ten CCR effluent discharge sites from coal ash ponds in $\mathrm{NC}$ and $\mathrm{TN}$; and (c) surface water and porewaters in river and lake systems affected by CCR effluent discharge in NC. The combination of the geochemical indicators from the laboratory experiments and environmental sampling provides a unique and practical identification method for evaluating the impact of CCRs on the environment.

\section{MATERIALS AND METHODS}

Field Sampling and Leaching Experiments. CCR samples were collected from 14 coal fired power/steam plants burning an assortment of coals from the Appalachian, Illinois, and Powder River Basins in the U.S.. All of the fly ash samples (Table 1) from the TVA Fossil Plants (John Sevier, Bull Run, and Kingston), the Duke University Steam Plant, as well as the samples collected by Jim Hower of the University of Kentucky (from plants coded PRB, E, M, G, I, TS, LM, K, and R) were leached according to EPA Method 1316 (varying solid to liquid ratios). The leaching test results reported in this paper are from the 0.1 solid to deionized water ratio portion of the Method 1316 leaching procedure. ${ }^{28}$ The ash samples were collected in new I-Chem certified Nalgene liter bottles, and kept in the custody of the sampler until returning to the laboratory, where they were put in a refrigerator in a locked, limited access room. Trace metal free VWR centrifuge tubes were used for the leaching experiments, along with ultrapure (type 1) water. Additional QA/QC information can be found in Ruhl et al. 2009, 2010, and 2012.8,9,29

Field trips were made to the Tennessee Valley Authority Kingston Fossil Plant CCR spill site between January 2009 and June 2011, and over 270 surface and porewater samples were collected during high (winter) and low (summer-fall) river flow regimes. ${ }^{9,29}$ Field trips were also made to lakes and rivers in North Carolina associated with disposal of CCR wastewater between August 2010 and February 2012. ${ }^{8}$ Surface and porewater samples were collected monthly from $\mathrm{Hyco}$ and Mayo Lakes from August 2010 through August 2011, and the other water bodies sampled at least once include Lake Norman, Mountain Island Lake, Lake Wylie, Dan River, French Broad River, and Jordan Lake as a reference lake. ${ }^{8}$ Water sampling strictly followed USGS protocols. ${ }^{30}$ After filtration of samples in the field $(0.45 \mu \mathrm{m}$ syringe filters), trace elements were measured by inductively coupled plasma mass spectrometry (ICP-MS), major elements by direct current plasma optical emission spectrometry (DCP-OES), and anions by ion chromatography (IC). Porewaters were extracted from river bottom sediments obtained using a Wildco box core (up to 25 $\mathrm{cm}$ depth), VibeCore (up to $182 \mathrm{~cm}$ depth), or peat core (up to $100 \mathrm{~cm}$ depth). All samples collected in the box core were homogenized after collection, while the VibeCore and peat core 

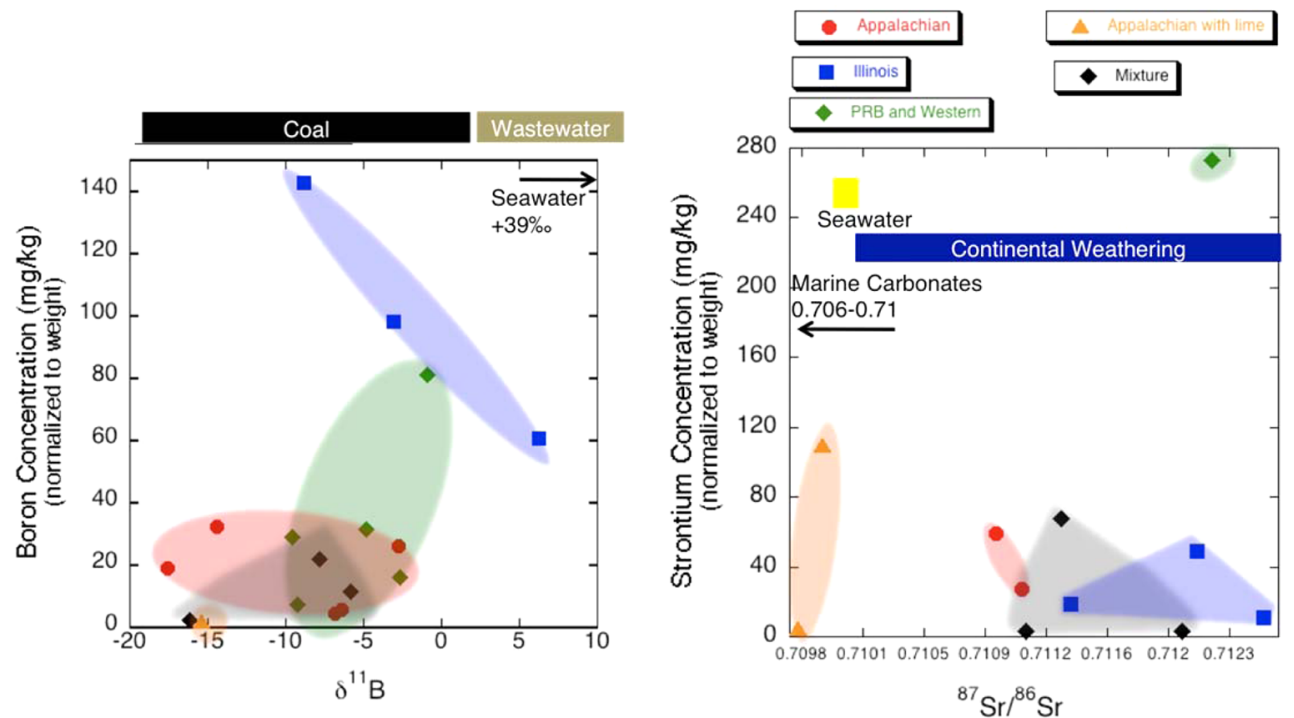

Figure 1. Range of elemental boron and strontium as well as $\delta^{11} \mathrm{~B}$ and ${ }^{87} \mathrm{Sr} /{ }^{86} \mathrm{Sr}$ in major U.S. coal basins detected in effluents from leaching experiments. The ranges of coal $\delta^{11} \mathrm{~B}$ values are from Williams and Hervig ${ }^{14}$ and the Sr isotopic values are from Hurst et al. ${ }^{23}$

samples were not homogenized but kept intact and analyzed at depth intervals. The sediment samples were either vacuum pump filtrated in the field or were centrifuged in the laboratory to extract the porewater. Porewater samples were then decanted, filtered, and analyzed.

Boron Isotopes. Boron from surface water, effluents, and leachates was processed through cation-exchange resin (AG $50 \mathrm{~W}-\mathrm{x} 8 \mathrm{Resin}$ ) to remove all cations (a particular interference of $\mathrm{Ca}$ with the $\mathrm{BO}^{2-}$ ions), treated with peroxide to remove organic matter and $\mathrm{CNO}$ complexes, loaded on the Triton (Thermo) thermal ionization mass spectrometer at Duke University and measured as $\mathrm{BO}^{2-}$ ions on low-temperature negative ion method developed recently by Dywer and Vengosh. ${ }^{31}$ All sample loading was carried out in a vertical laminar flow clean hood equipped with boron-free PTFE HEPA filtration. Data on standards (NIST951, OISL Atlantic seawater, and IAEA Groundwater B-3) loaded using this method yield external precision of approximately $0.5 \% 0 \delta^{11} \mathrm{~B}$. The average boron ratio received for NIST951 during these analyses was 4.00281 . The variability within replicates was $\pm 1.5 \%$. Total loading blank is $<15 \mathrm{pg} \mathrm{B}$ as determined by isotope dilution (NIST951). The load solution delivers ionization efficiency similar to seawater and has negligible $\mathrm{CNO}^{-}$(mass 42) interference, based on negligible signal at proxy mass $26\left(\mathrm{CN}^{-}\right)$.

Strontium Isotopes. Strontium from surface water, effluents, and leachates was evaporatively preconcentrated in HEPA filtered clean hood and redigested in $0.6 \mathrm{~mL}$ of $3.5 \mathrm{~N}$ $\mathrm{HNO}_{3}$ from which strontium was separated using Eichrom Srspecific ion-exchange resin. Approximately 1 to $10 \mu \mathrm{g} \mathrm{Sr}$ was loaded onto outgassed single rhenium filaments along with a tantalum oxide $(\mathrm{TaO})$ activator solution and loaded onto the Triton TIMS at Duke University. Samples and standards were gradually heated to obtain an ${ }^{88} \mathrm{Sr}$ beam intensity of $\sim 3 \mathrm{~V}$, after which 220 cycles of data were collected yielding a typical internal precision of $\sim 0.000004$ for ${ }^{87} \mathrm{Sr} /{ }^{86} \mathrm{Sr}$ ratios (1 sd). External reproducibility on standard NIST987 yielded a mean ${ }^{87} \mathrm{Sr} /{ }^{86} \mathrm{Sr}$ ratio of $0.710265 \pm 0.000009(1 \mathrm{sd})$.

\section{RESULTS AND DISCUSSION}

Elemental Boron and Strontium and Their Isotope Ratios in Coal Combustion Residuals. Coal combustion residuals can vary widely in their chemical and mineralogical composition due to variations in their source coals, combustion temperature and processing, as well as postcombustion treatment. ${ }^{6,7}$ Boron and strontium are highly abundant and easily leached off of CCRs, ${ }^{6,9,29}$ and therefore have been suggested to be good indicators of CCR leachate. ${ }^{8}$ The results from the 0.1 solid to deionized water leaching show a wide range of concentrations of leachable constituents from the fly ash (e.g., B ranged from $1 \mathrm{ppm}$ to $>140 \mathrm{ppm}$ normalized to weight) (Table 1 ). In addition to $\mathrm{Ca}, \mathrm{Mg}, \mathrm{V}, \mathrm{Mo}, \mathrm{Ba}$, and $\mathrm{Li}, \mathrm{Sr}$ had also elevated concentrations in the CCR leachates (5-273 $\mathrm{ppm}$, normalized to weight). In this study we investigated CCRs sourced from a variety of coal basins (Appalachian, Illinois, and Powder River) and found large variations in elemental leachate concentrations, which vary with the coal source burned at the different plants (Table 1). For example, the Illinois basin coal ash had the highest boron concentration of all of the other sources sampled, with concentrations ranging from 60 to $142 \mathrm{ppm}$ (normalized to weight), while the Appalachian and Powder River Basin (PRB) (and mixtures) had much lower boron concentrations (below 32 ppm B). In contrast, the PRB had the greatest concentration of strontium (273 ppm) and the mixture of Appalachian and PRB had the second greatest concentration (95 ppm), while the Appalachian and Illinois Basins had $\mathrm{Sr}$ concentrations less than $60 \mathrm{ppm}$. In addition to the coal sources, we observed variations in the leachable concentrations in CCRs in different units within the same plant (SI Table S1). Fly ash was sampled from seven units within one plant and individually tested with the same 0.1 solid to deionized water ratio (SI Table S1). The different units represent variations seen in the plant due to actual process differences in coal handling within the plant, temperature of fly ash collection, pulverizer efficiency, and particle size differences at each unit. ${ }^{6,7,12,32-35}$ The units showed a range in $\mathrm{Sr}(50-85$ $\mathrm{ppm}$ ) and $\mathrm{B}$ concentration (4-35 ppm), yet they are from the same source coal (App/PRB Mixture). These differences demonstrate the potential heterogeneity of elements that can 

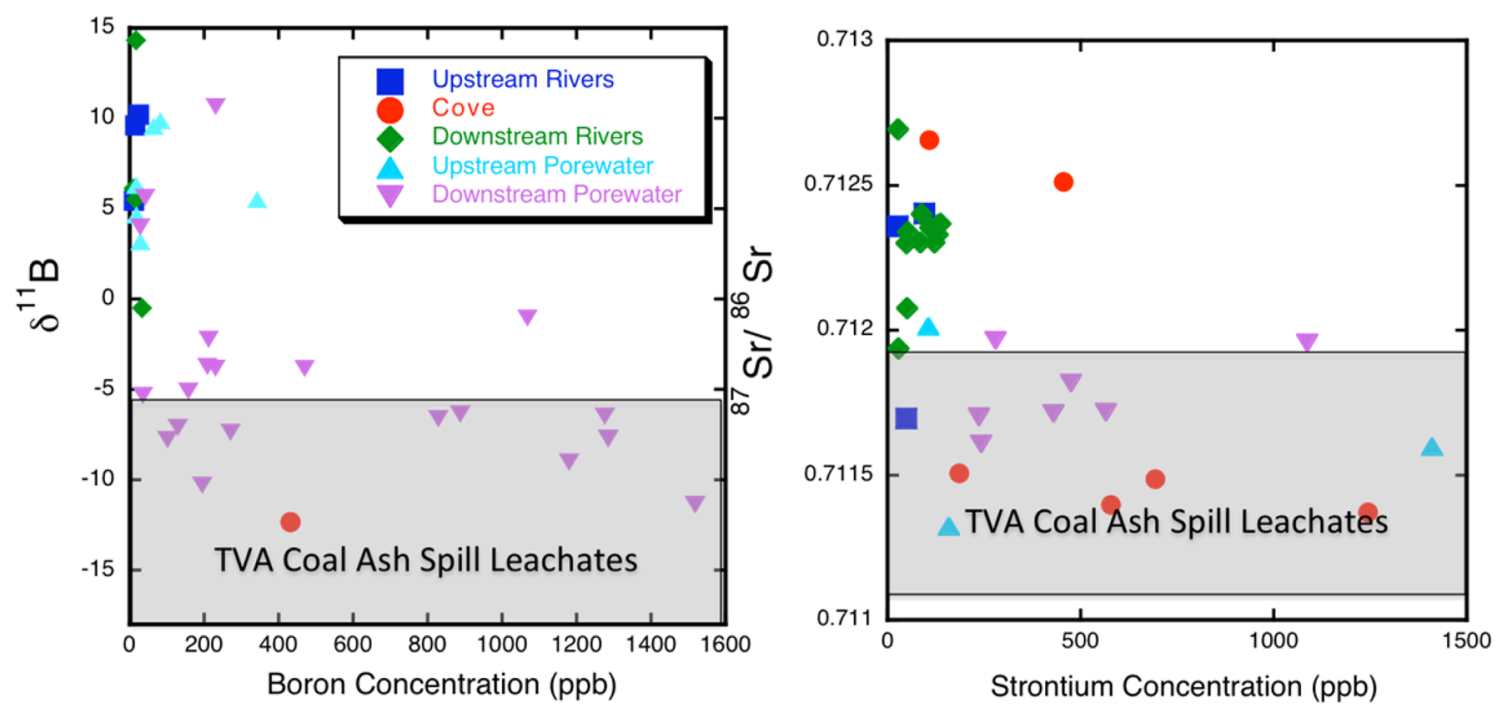

Figure 2. $\delta^{11} \mathrm{~B}$ versus $\mathrm{B}$ concentration (left) and the ${ }^{87} \mathrm{Sr} /{ }^{86} \mathrm{Sr}$ vs $\mathrm{Sr}$ concentration (right) of the TVA Spill area waters (surface and pore water sorted by location and type) compared to the $\delta^{11} \mathrm{~B}$ and ${ }^{87} \mathrm{Sr} /{ }^{86} \mathrm{Sr}$ ranges in leaching experiments conducted on the spilled ash collected at the TVA site (gray shaded area).

be leached from CCRs from the same plant. This chemical heterogeneity also complicates the ability to trace the CCR contaminants in the environment based on elemental analysis as CCRs do not have a uniform $\mathrm{B} / \mathrm{Sr}$ ratio and thus additional tools, such as isotopic tracers are needed to have a better assessment of the environmental fate of CCR leachates.

Previous studies have shown that U.S. coals and CCRs are characterized by low $\delta^{11} \mathrm{~B}$ values, ${ }^{14,17}$ which are relatively distinctive from other common boron sources in the environment (Figure 1). In this study we have expanded the CCR sample collection and included systematic CCR sampling originated from the major coal basins in the U.S. (Table 1). The boron isotopic ratios from the 0.1 solid to deionized water leaching-tests had a $\delta^{11} \mathrm{~B}$ range of $-18 \%$ to $+7 \%$ (Figure 1 ). These results are similar to previously published values for CCRs, ranging from $-19 \%$ o to $+16 \%$. . $^{17,18,36}$ Previous studies have considered the isotopic variations linked to coal rank, but $\delta^{11} \mathrm{~B}$ of different CCRs were inconsistent with such a trend (i.e., bituminous and lignite fly ashes had negative $\delta^{11} \mathrm{~B}$ while the sub-bituminous coal fly ash had a positive $\left.\delta^{11} \mathrm{~B}\right) .{ }^{17}$ Figure 1 shows that CCRs derived from the Appalachian basin coals had $\delta^{11} \mathrm{~B}$ range of $-18 \%$ o to $-14 \%$, Powder River Basin (PRB) had a $\delta^{11} \mathrm{~B}$ of $-4 \%$, and a blend of Appalachian and PRB had $\delta^{11} \mathrm{~B}$ value of $-8 \%$. The CCRs originated from coal from the Illinois basin with the highest $\mathrm{B}$ contents had the widest $\delta^{11} \mathrm{~B}$ range of $-8 \%$ o to $+7 \%$. Overall, the boron isotopic signatures of CCR leachates indicate that CCRs have some variations of $\delta^{11} \mathrm{~B}$ that seem to be related to different coal sources.

Strontium isotope ratios were also recognized as a possible CCR tracer. ${ }^{27,37}$ It has been shown that Sr isotopic ratios for CCRs can be characterized by coal rank, ${ }^{37}$ in which the ${ }^{87} \mathrm{Sr} /{ }^{86} \mathrm{Sr}$ ratio increases with coal maturity: lignites of 0.70767 , subbituminous of 0.70874 , and bituminous coal of $0.71022 .{ }^{37} \mathrm{It}$ was suggested that this isotopic trend is due to different $\mathrm{Sr}$ sources at different stages of coalification, with the lower rank coals containing more $\mathrm{Sr}$ bearing carbonate and sulfate minerals. ${ }^{37}$ Yet differentiating ${ }^{87} \mathrm{Sr} /{ }^{86} \mathrm{Sr}$ based on coal rank could be misleading, due to the fact that the rank of coal does not dictate its geological origin, nor its age, which can have a major impact on its isotopic composition. The coal ash reported in Mattigod et al. ${ }^{37}$ were collected from plants in the U.S., but without identification of the coal source. The ${ }^{87} \mathrm{Sr} /{ }^{86} \mathrm{Sr}$ isotopic ratio of the CCR leachates in this study ranged from 0.7109 to 0.7126 (Figure 1). The data show that the ${ }^{87} \mathrm{Sr} /{ }^{86} \mathrm{Sr}$ isotopic ratios of the Appalachian Basin coals had the least radiogenic ratio (0.7109-0.71108), while CCR leachates originated from coals from PRB had a more radiogenic ratio (0.71221), and CCR leachates from Illinois Basin had a broader range of ${ }^{87} \mathrm{Sr} /{ }^{86} \mathrm{Sr}$ ratios (0.71137 to 0.7125 ) (Figure 1). These ratios are inconsistent with the $\mathrm{Sr}$ ratios subdivided by coal rank. Appalachian and Illinois coals are generally characterized as bituminous, while the PRB coal composed of subbituminous to lignite (less common). ${ }^{38}$ Some of the isotopic variations could be due to different geological conditions for the depositional environment of the Appalachian and Illinois coals. While the age of both the Appalachian and Illinois coals is Pennsylvanian, they were formed in different depositional settings. The Appalachian coals were formed in a foreland basin ${ }^{39}$ and the Illinois coals in a paralic basin with marine and nonmarine deposits. ${ }^{40}$ Additionally, the coal from the Powder River Basin is much younger (Tertiary age) and was originated in an inland basin/alluvial depositional history. ${ }^{40}$

Environmental Applications. The 2008 TVA Coal Ash Spill. One of the world's largest CCR spills in U.S. history occurred in December 2008 at the Tennessee Valley Authority's Kingston Fossil Plant in Kingston, TN. The breach of a retention pond resulted in over 4.1 million cubic meters of wet CCRs spilled into the Emory and Clinch Rivers as well as the surrounding land surface. ${ }^{41}$ The results from the TVA spill confirmed that boron can be a sensitive indicator for metals leaching from CCRs, with boron content up to $1600 \mu \mathrm{g} / \mathrm{L}$ in downstream porewater in ash covered sediments, relative to the upstream and uncontaminated river water with boron of 6-9 $\mu \mathrm{g} / \mathrm{L}$ (Figure 2) ${ }^{9,29}$ Results from surface water at a site covered with spilled ash and limited water exchange (known henceforth as the Cove $)^{9,29}$ yielded low $\delta^{11} \mathrm{~B}$ values of $-12 \%$, which is consistent with our leaching experiments of the same TVA coal ash $(-18 \%$ o to $-14 \%)$. The low $\delta^{11} \mathrm{~B}$ is significantly different from that of meteoric boron, as demonstrated by the $\delta^{11} \mathrm{~B}$ 

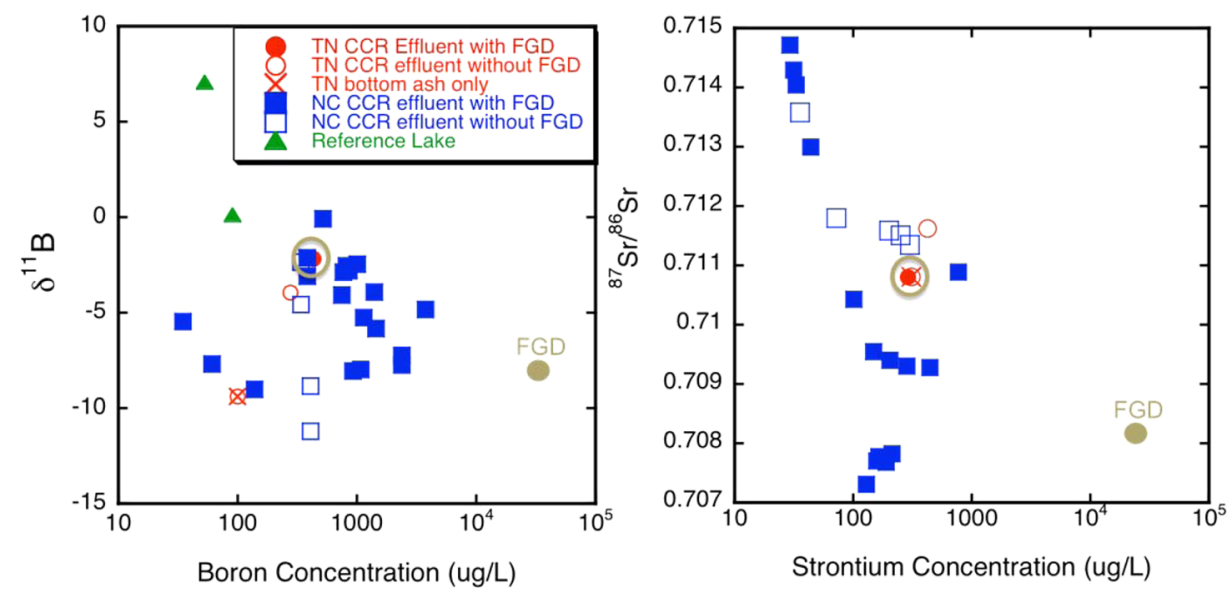

Figure 3. $\delta^{11} \mathrm{~B}$ and ${ }^{87} \mathrm{Sr} /{ }^{86} \mathrm{Sr}$ values versus boron and strontium concentrations of CCR effluents from Tennessee and North Carolina coal fired power plants. The data are sorted by location and association with an FGD system. The brown points on both graphs represent an actual FGD sample. The brown circles in both figures outline the bulk sample after combining with the FGD waste stream (indicated with a brown solid circle and the words FGD).

values of the uncontaminated upstream Emory $(+9.6 \%)$ and Clinch $(+10.2 \% 0)$ rivers (Figure 2$)$.

Similar to boron, water in the ash spill area (Cove) had high Sr concentrations (up to $1240 \mu \mathrm{g} / \mathrm{L}$ ) relative to the pristine upstream Emory River $(25 \mu \mathrm{g} / \mathrm{L})$ and Clinch River $(90 \mu \mathrm{g} / \mathrm{L})$ (Figure 2). The ${ }^{87} \mathrm{Sr} /{ }^{86} \mathrm{Sr}$ ratios found in the surface water in the Cove $(0.7110$ to 0.7128$)$ are consistent with the ratio measured in experimental leachates of the TVA spilled CCRs (0.712) (Figure 2). Yet the ${ }^{87} \mathrm{Sr} /{ }^{86} \mathrm{Sr}$ ratios in the upstream Emory and Clinch River were 0.7117-0.7124 and 0.7124, respectively. This isotopic range overlaps the ${ }^{87} \mathrm{Sr} /{ }^{86} \mathrm{Sr}$ in the downstream river (0.7119 to 0.7127$)$. This demonstrates that in spite of the high concentration of $\mathrm{Sr}$ in CCR leachates, there could be circumstances that $\mathrm{Sr}$ isotopes could not be used as distinguishing tracers for elucidating the CCR leachates due to similar isotopic fingerprints of noncontaminated waters and CCRs. Overall, the range of ${ }^{87} \mathrm{Sr} /{ }^{86} \mathrm{Sr}$ isotopic ratio in CCRs is 0.7109 to 0.7126 , excluding lime addition. This isotopic range limits the capability of the Sr tracer to be used in watersheds where the ${ }^{87} \mathrm{Sr} /{ }^{86} \mathrm{Sr}$ isotopic ratios are different. Attempts to model and map the ${ }^{87} \mathrm{Sr} /{ }^{86} \mathrm{Sr}$ variations in watersheds in the $\mathrm{US}^{42,43}$ show that most of the southeastern, south, and central watersheds in the coterminous U.S. have a similar isotopic range that would mask the difference between CCR-impacted and naturally occurring background waters. Yet in other areas of the northeastern, northern, and western U.S., the isotopic ratios are either higher (e.g., northeastern U.S., Minnesota, southern Appalachian range) or lower (e.g., Southern Texas, Oregon) that would allow a clear distinction between CCRimpacted water and natural background.

CCR Effluent Discharges. CCR effluents were sampled from ten coal fired power plants in North Carolina ${ }^{8}$ and Tennessee from August 2010 until August 2011. The chemical composition of discharged effluents at the effluent outfall sites showed high concentrations of several elements that characterize CCRs (e.g., B, Sr, Mo, V) that are significantly enriched relative to the upstream source water. ${ }^{8}$ Our data show that all of the CCR effluents were characterized by elevated boron concentrations and relatively low $\delta^{11} \mathrm{~B}$ values ranging from $-12 \%$ o to $-0.2 \%$ (Figure 3 ). The range of boron isotope ratios measured in the effluents could be indicative of the various processes undertaken in the plant as well as the coal sources. For instance, one of the TN plants (John Sevier) disposes of their fly ash in a dry manner and therefore only transports the bottom ash to the associated coal ash pond and thus the discharged effluent reflects leaching of bottom ash rather than bulk fly ash.

The data from the CCR effluents indicate that the FGD effluent had higher boron concentrations than those effluents without FGD. Yet we found no significant difference in the $\delta^{11} \mathrm{~B}$ between the FGD and non-FGD effluents, which indicates that the FGD process does not add a significant source of boron from the injected carbonate or lime, but rather captures more of the volatile boron from the combusted coal before it escapes the smokestacks. The NC and TN coal plants sampled were burning Appalachian coals during the sampling period, except for one TN plant that was burning a 60/40 mixture of Appalachian and PRB coals (Table 1 ). The $\delta^{11} \mathrm{~B}$ values of the effluents from these plants are consistent with those of the leaching experiments performed for the selected CCRs sorted by coal basin origin (Figure 1).

The ${ }^{87} \mathrm{Sr} /{ }^{86} \mathrm{Sr}$ ratios in the North Carolina CCR effluents ranged from 0.7075 to 0.7147 , while the Tennessee CCR effluents had a narrow range from 0.7107 to 0.7117 (Figure 3). The only available FGD effluent sample (from the Bull Run Fossil Plant, TN) had a very high $\mathrm{Sr}$ concentration $(>10000$ $\mathrm{ug} / \mathrm{L}$ ) and a significantly lower ${ }^{87} \mathrm{Sr} /{ }^{86} \mathrm{Sr}$ ratio of 0.708 relative to the other CCR effluents. The bulk CCR effluents of the same plant (combined with FGD) had lower Sr concentration (500 ug/L) and higher ${ }^{87} \mathrm{Sr} /{ }^{86} \mathrm{Sr}$ (0.71081; Figure 3). At the same time, experimental leaching of coal ash from the same plant yielded a higher ${ }^{87} \mathrm{Sr} /{ }^{86} \mathrm{Sr}$ (0.71108). These results indicate that the $\mathrm{Sr}$ isotope composition of FGD effluents is different from the non-FGD effluents with a nonradiogenic ${ }^{87} \mathrm{Sr} /{ }^{86} \mathrm{Sr}$ ratio, presumably derived from the added lime. It also demonstrates that the bulk CCR effluents discharging from this plant $\left.{ }^{87} \mathrm{Sr} /{ }^{86} \mathrm{Sr}=0.71081\right)$ represent a mixture of Sr derived from leaching of coal ash (0.71108) and FGD (0.708) effluents.

As mentioned above, the NC and TN plants were burning Appalachian basin coals during the sampling period, except for one TN plant that was burning a $60 / 40$ mixture of Appalachian/PRB coals. The isotopic ratios of some of the North Carolina CCR effluents were consistent with the Appalachian isotopic range (Figure 1) determined by the 

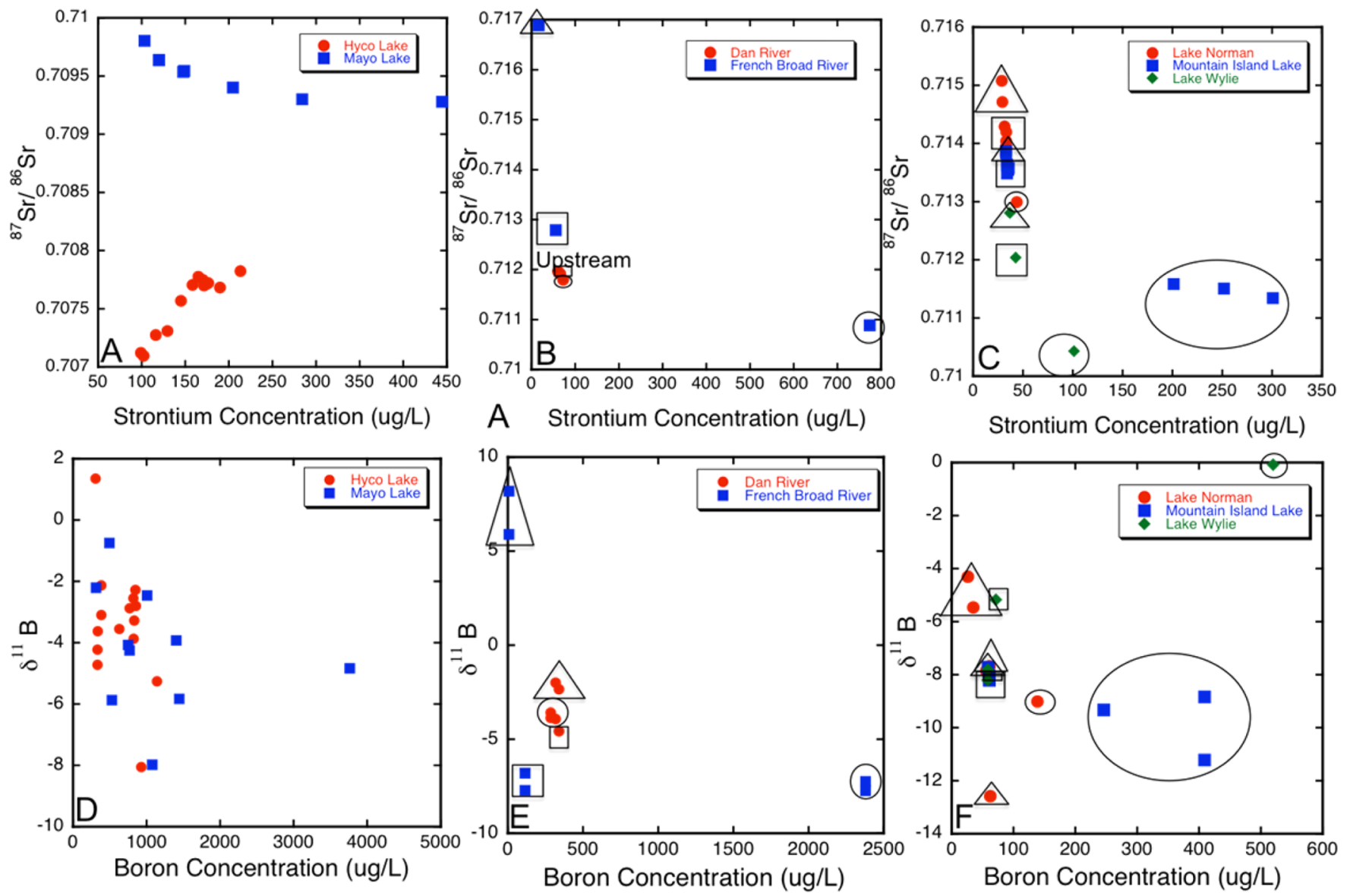

Figure $4 .{ }^{87} \mathrm{Sr} /{ }^{86} \mathrm{Sr}$ versus strontium concentrations (top row- Figures $\mathrm{A}, \mathrm{B}, \mathrm{C}$ ) and $\delta^{11} \mathrm{~B}$ versus boron concentrations (bottom row- Figures D, E, F) in CCR effluents discharged into North Carolina waters. Each outfall (circles) had a distinctly different Sr isotopic value relative to the upstream ${ }^{87} \mathrm{Sr} /{ }^{86} \mathrm{Sr}$ values (triangles). This indicates that locally, ${ }^{87} \mathrm{Sr} /{ }^{86} \mathrm{Sr}$ values may be used as a tracer. The boron isotope of most water bodies had different ratios at the outfall (circles) compared to upstream (triangles) while Hyco and Mayo lakes show evidence of CCRs (negative $\delta^{11} \mathrm{~B}$ ) throughout the lakes. The downstream samples (squares) in figures B, C, E, and F reveal a shift toward the outfall values in their ${ }^{87} \mathrm{Sr} /{ }^{86} \mathrm{Sr}$ or $\delta^{11} \mathrm{~B}$ values.

leaching experiments, but several sites had both higher and lower radiogenic ratios relative to the Appalachian range. The decrease in ${ }^{87} \mathrm{Sr} /{ }^{86} \mathrm{Sr}$ ratio could be a result of the contribution of the FGD effluents in which lime or limestone with typically lower ${ }^{87} \mathrm{Sr} /{ }^{86} \mathrm{Sr}$ ratio $(\sim 0.7068-0.7095){ }^{44}$ were added to the flue gas, introducing an additional $\mathrm{Sr}$ component with a lower isotopic ratio to the effluent. The $\mathrm{Sr}$ isotope ratios of the Tennessee effluents were consistent with the ratios measured in the leaching experiments, whether they were from the Appalachian or the mixture of Appalachian and PRB coals. Overall, these results indicate that effluents from CCRs without the FGD system may be more representative of the ranges determined by the leaching experiments (Figures 1,3, S1-S3), while the ratios measured in FGD effluents show a typically lower ${ }^{87} \mathrm{Sr} /{ }^{86} \mathrm{Sr}$ signature.

Tracing the Impact of CCRs on Water Quality in North Carolina. The low $\delta^{11} \mathrm{~B}$ imprint of the CCR effluents is different from that of common boron in uncontaminated water resources in NC. This was demonstrated by the composition of Jordan Lake, which was used as a reference lake in NC with no CCR input. Jordan Lake had low B $(<100 \mathrm{ug} / \mathrm{L})$ and $\delta^{11} \mathrm{~B}$ values ranging from $0 \%$ to $+7 \%$ o. In order to evaluate the CCR impact on NC water resources that receive CCR effluents, samples were collected from both upstream and downstream of the CCR effluent outfalls. The boron concentrations of the CCR effluents were high relative to the upstream waters ${ }^{8}$
(Figure 4). The $\delta^{11} \mathrm{~B}$ values of the rivers and lakes at and downstream from the outfall sites were lower relative to the upstream sites (Figure 4E and F). The only exceptions we found were in lakes with high CCR discharge volume and long residence time (Hyco and Mayo Lakes), in which the lake water is recycled for cooling the coal fired power plants. In these cases, the lakes had an even distribution of low $\delta^{11} \mathrm{~B}$ values $(-8 \%$ o to $+2 \%$ ) because the source of boron for the lake was primarily the CCRs effluent discharge (>1000 ppb) relative to the low boron in the natural streams input $(<10$ $\mathrm{ppb})$. In systems where water is not recycled through the power plants, we observed a sharp increase in B concentration and a drop in $\delta^{11} \mathrm{~B}$ at the outfall, relative to the upstream waters (with one exception in Lake Wylie). The downstream waters had a composition that reflects a mixture of the upstream waters and CCR effluents. For instance, the upstream French Broad River near Ashville NC had boron concentration of $8 \mathrm{ug} / \mathrm{L}$ and $\delta^{11} \mathrm{~B}$ of $+8 \%$, while the CCR effluents had B concentration of 2380 $\mathrm{ug} / \mathrm{L}$ and $\delta^{11} \mathrm{~B}$ of $-7.7 \%$. The downstream mixture resulted in a boron concentration of $115 \mathrm{ug} / \mathrm{L}$ and $\delta^{11} \mathrm{~B}$ of $-7 \%$, reflecting the influence of the CCR effluent discharge into the river (Figure 4). A simple mass-balance calculation shows that in this case the contribution of the CCR input to the downstream river is about $5 \%$ (i.e., $5 \%$ of the dissolved constituents of the river is derived from CCR effluent discharge) (see Supporting Information (SI)). Consequently, 
the boron isotope geochemistry provides a very sensitive methodology to quantify CCR input to water resources with resolution of less than $5 \%$.

The $\mathrm{Sr}$ isotope ratios in rivers and lakes that receive CCR effluents samples in NC revealed mixing relationships between the upstream (nonimpacted) waters and the CCR effluents (Figure 4). All outfall and downstream sites had higher Sr and lower ${ }^{87} \mathrm{Sr} /{ }^{86} \mathrm{Sr}$ ratios (with the exception of Hyco Lake) relative to the upstream samples (Figure 4) that reflect a mixture between CCR effluents and background waters. We used the $\mathrm{Sr}$ isotope variation to quantify the mixing fraction of CCR effluents in Hyco and Mayo Lakes, showing a CCR contribution to dissolved salts in the lake water of $88 \%$ to $98 \%$ in Hyco Lake and $46 \%$ to $69 \%$ in Mayo Lake. The ${ }^{87} \mathrm{Sr} /{ }^{86} \mathrm{Sr}$ ratios of the CCR effluents from North Carolina were different from the composition of regional surface water and thus provided a clear distinction between contaminated and pristine water. This distinction was not possible for the case of the TVA spill because of the overlap in the ${ }^{87} \mathrm{Sr} /{ }^{86} \mathrm{Sr}$ ratios of CCR effluents and the background waters.

Porewaters in CCR Impacted Lakes. Porewater extracted from the lake bottom sediments was sampled at Hyco and Mayo Lakes in the North Carolina. Porewater from the top 25 $\mathrm{cm}$ of the sediment column had slightly lower concentrations of boron ( $817 \mathrm{ppb}$ relative to $1142 \mathrm{ppb}$ in surface water) but a similar $\delta^{11} \mathrm{~B}$ range relative to the overlying surface water at Hyco and Mayo Lakes ( $-8 \%$ o to $-0.5 \%$; SI Figure S4). A long core was also collected at Hyco Lake near the effluent discharge point, capturing up to $52 \mathrm{~cm}$ deep within the bottom lake sediment column. The boron concentrations decreased from $817 \mathrm{ug} / \mathrm{L}$ to $81 \mathrm{ug} / \mathrm{L}$, while the $\delta^{11} \mathrm{~B}$ increased from $-5.5 \%$ to $+5.5 \%$ with sediment depth (SI Figure S4). Chloride in porewaters, which behaves conservatively in the lake, ${ }^{8}$ also decreased with depth from $58 \mathrm{mg} / \mathrm{L}$ to $26 \mathrm{mg} / \mathrm{L}$; a 2 -fold decrease relative to 10 -fold reduction for boron. The $\mathrm{B} / \mathrm{Cl}$ ratio, therefore, decreased with depth and parallel to a $10 \%$ o increase in $\delta^{11} \mathrm{~B}$ (SI Figure S4). This suggests that boron in the porewater was adsorbed by the sediments, in addition to a general shift in the porewater chemistry along the $52 \mathrm{~cm}$ core. Numerous studies have shown that the association of boron depletion and ${ }^{11} \mathrm{~B}$ enrichment due to the preferential retention of the light boron isotope $\left({ }^{10} \mathrm{~B}\right)$ from the water on sediments, resulting in ${ }^{11} \mathrm{~B}$ enrichment in the residual porewaters. ${ }^{45-48}$

Overall, this study reveals that despite some isotopic variations in the coal sources, combustion procedures, and post treatment such as FGD, the boron and strontium isotopic fingerprints of leachates generated from CCRs are unique and in many cases different from uncontaminated water and/or other anthropogenic contamination sources. While the boron isotopes are shown to be universally applicable for tracing CCR contaminants in the environment, the application of strontium isotopes is more restricted to specific cases where the $\mathrm{Sr}$ isotopic composition of the background water is different from that of CCRs. The application of boron and strontium isotopes, combined with the geochemical characteristics therefore provides therefore a novel tool for identifying CCR effluents and quantifying their impact on the environment.

\section{ASSOCIATED CONTENT}

\section{S Supporting Information}

Supporting Information includes 4 figures and 1 table. This material is available free of charge via the Internet at http:// pubs.acs.org.

\section{AUTHOR INFORMATION}

\section{Corresponding Author}

*E-mail: 1sruhl@ualr.edu.

\section{Notes}

The authors declare no competing financial interest.

\section{ACKNOWLEDGMENTS}

Different parts of this project were funded by NSF (Grant No. Cbet-1235661) and ORAU (Grant No. 7-22975), as well as contributions from Fred and Alice Stanbeck to the Nicholas School of the Environment. Part of this work was conducted with Autumn Romanski and S. Danny Smith from the North Carolina Department of Environment and Natural Resources. We thank and acknowledge Jennie Harkness, Grace Schwartz, Amrika Deonarine, Nathanial Warner, R. Brittany Merola, and Alissa White for their field and laboratory assistance.

\section{REFERENCES}

(1) Energy Information Administration, U. S. Short-Term Energy Outlook. 2014. http://www.eia.gov/forecasts/steo/pdf/steo_full.pdf.

(2) Energy Information Administration, U. S. Department of Energy. Electric Power Annual 2013. 2013. http://www.eia.gov/electricity/ annual/pdf/epa.pdf.

(3) Environmental Protection Agency. Frequent Questions: Coal Combustion Residues (CCR) - Proposed Rule. 2013. http://www.epa. gov/wastes/nonhaz/industrial/special/fossil/ccr-rule/ccrfaq.htm\#19.

(4) American Coal Ash Association. 2008 Coal Combustion Product (CCP) Production and Use Survey Report. 2009. http://www.acaausa.org.

(5) U.S. Environmental Protection Agency. Steam Electric Power Generating Point Source Category: Final Detailed Study Report. 2009.

(6) Adriano, D. C.; Page, A. L.; Elseewi, A. A.; Chang, A. C.; Straughan, I. Utilization and disposal of fly-ash and other coal residues in terrestrial ecosystems-A review. J. Environ. Qual. 1980, 9, 333344.

(7) Mardon, S. M.; Hower, J. C. Impact of coal properties on coal combustion by-product quality: Examples from a Kentucky power plant. Int. J. Coal Geol. 2004, 59, 153-169.

(8) Ruhl, L.; Vengosh, A.; Dwyer, G. S.; Hsu-Kim, H.; Schwartz, G. E.; Romanski, A.; Smith, D. S. The impact of coal combustion residual effluent on water resources: A North Carolina case study. Environ. Sci. Technol. 2012, 46, 12226-12233.

(9) Ruhl, L.; Vengosh, A.; Dwyer, G. S.; Hsu-Kim, H.; Deonarine, A. Environmental Impacts of the coal ash spill in Kingston, Tennessee: An 18-month survey. Environ. Sci. Technol. 2010, 44, 9272-9278.

(10) Sajwan, K. S. Coal Combustion Byproducts and Environmental Issues; Springer: New York, 2006, .

(11) Hower, J. C.; Robl, T. L.; Anderson, C.; Thomas, G. A.; Sakulpitakphon, T.; Mardon, S. M.; Clark, W. L. Characteristics of coal combustion products (CCP's) from Kentucky power plants, with emphasis on mercury content. Fuel 2005, 84, 1338-1350.

(12) Hower, J. C.; Sakulpitakphon, T.; Trimble, A. S.; Thomas, G. A.; Schram, W. H. Major and minor element distribution in a coal-fired utility boiler in KY. Energy Sources 2006, 28, 79-95.

(13) Hower, J. C.; Trimble, A. S.; Eble, C. F.; Palmer, C.; Kolker, A. Characterization of fly ash from low-sulfur and high-sulfur coal sources: Partitioning of carbon and trace elements with particle size. Energy Sources 1999, 21, 511-525.

(14) Williams, L. B.; Hervig, R. L. Boron isotope composition of coals: A potential tracer of organic contaminated fluids. Appl. Geochem. 2004, 19, 1625-1636.

(15) Vengosh, A.; Heumann, K. G.; Juraske, S.; Kasher, R. Boron isotope application for tracing sources of contamination in groundwater. Environ. Sci. Technol. 1994, 28, 1968-1974.

(16) Warner, N. R.; Darrah, T. H.; Jackson, R. B.; Millot, R.; Kloppmann, W.; Vengosh, A. New Tracers identifying hydraulic 
fracturing fluids and accidental releases from oil and gas operations. Environ. Sci. Technol. 2014, 48, 12552-12560.

(17) Davidson, G. R; Bassett, R. L. Application of boron isotopes for identifying contaminants such as fly ash leachate in groundwater. Environ. Sci. Technol. 1993, 27, 172-176.

(18) Spivak-Birndorf, L. J.; Stewart, B. W. Use of boron isotopes to track the interaction of coal utilization byproducts with water in the environment. In The Geological Society of America, 2006 Philadelphia Annual Meeting, October 22-25, 2006.

(19) Tishmak, J. K.; Burns, P. E. The chemistry and mineralogy of coal and coal combustion products. Geol. Soc. 2004, 236, 223-246.

(20) Jankowski, J.; Ward, C. R.; French, D.; Groves, S. Mobility of trace elements from selected Australian fly ashes and its potential impact on aquatic ecosystems. Fuel 2006, 85, 243-256.

(21) Faure, G. The Principles of Isotope Geology; Wiley: New York, NY, 1986, .

(22) Campbell, C. E.; Pearson, B. N.; Frost, C. D. Strontium isotopes as indicators of aquifer communication in an area of coal-bed natural gas production, Powder River Basin, Wyoming and Montana. Rocky Mt. Geol. 2008, 43, 171-197.

(23) Hurst, R. W.; Davis, T. E.; Elseewi, A. A. Strontium isotopes as a tracer of coal combustion residue in the environment. Eng. Geol. 1991, 30.

(24) Brubaker, T. M.; Stewart, B. W.; Capo, R. C.; Schroeder, K. T.; Chapman, E. C.; Spivack-Birndorf, L. J.; Vesper, D. J.; Cardone, C. R.; Rohar, P. C. Coal fly ash interaction with environmental fluids: Geochemical and strontium isotope results from combined column and batch leaching experiments. Appl. Geochem. 2012, 32, 184-194.

(25) Vengosh, A.; Linberg, T. T.; Merola, R. B.; Ruhl, L.; Warner, N. R.; White, A.; Dwyer, G. S.; Di Giulio, R. T. The isotopic imprints of mountaintop mining contaminants. Environ. Sci. Technol. 2013, 47, 10041-10048.

(26) Spears, D. A.; Lee, S. Geochemistry of leachates from coal ash. Geol. Soc. Lon. 2004, 236, 619-639.

(27) Spivak-Birndorf, L. J.; Stewart, B. W.; Capo, R. C.; Chapman, E. C.; Schroeder, K. T.; Brubaker, T. M. Strontium isotope study of coal utilization by-products interacting with environmental waters. J. Environ. Qual. 2012, 41, 144-154.

(28) Agency, E. P. Liquid-Solid Partitioning as a function of liquid-tosolid ratio in solid materials using a parallel batch procedures. 2012 . http://www.epa.gov/osw/hazard/testmethods/sw846/pdfs/1316.pdf.

(29) Ruhl, L.; Vengosh, A.; Dwyer, G. S.; Hsu-Kim, H.; Deonarine, A.; Bergin, M.; Kravchenko, J. Survey of the potential environmental and health impacts in the immediate aftermath of the coal ash spill in Kingston, Tennessee. Environ. Sci. Technol. 2009, 43, 6326-6333.

(30) USGS. National Field Manual for the Collection of WaterQuality Data. 2008. 2009. http://water.usgs.gov/owq/FieldManual/ index.html.

(31) Dwyer, G.; Vengosh, A. Alternative filament loading solution for accurate analysis of boron isotopes by thermal ionization mass spectrometry. In American Geophysical Union, Fall Meeting, Abstract \#H51C-0824, 2008.

(32) Sakulpitakphon, T.; Hower, J. C.; Trimble, A. S.; Schram, W. H.; Thomas, G. A. Arsenic and mercury partitioning in fly ash at a Kentucky power plant. Energy Fuels 2003, 17, 1028-1033.

(33) Kaakinen, J. W.; Jorden, R. M.; Lawasani, M. H.; West, R. E. Trace-element behavior in a coal-fired power plant. Abst. Papers Am. Chem. Soc. 1975, 51-51.

(34) Klein, D. H.; Andren, A. W.; Carter, J. A.; Emery, J. F.; Feldman, C.; Fulkerson, W.; Lyon, W. S.; Ogle, J. C.; Talmi, Y. A.; Vanhook, R. I.; Bolton, N. E. Trace-element measurements at coal-fired allen steam plant mass balance and concentrations in fly ash. Abst. Papers Am. Chem. Soc. 1975, 50-51.

(35) Natusch, D. F. S. Physiochemical associations of trace contaminants in coal fly ash. Abst. Papers Am. Chem. Soc. 1975, 52-52.

(36) Buszka, P. M., Fitzpatrick, J., Watson, L. R.; Kay, R. T. Evaluation of Ground-Water and Boron Sources by Use of Boron StableIsotope Ratios, Tritium, And Selected Water Chemistry Constituents near
Beverly Shores, Northwwestern Indiana, 2004. Series; U.S. Geological Survey, 2004.

(37) Mattigod, S. V.; Rai, D.; Fruchter, J. S. Strontium isotopic characterization of soils and coal ashes. Appl. Geochem. 1990, 5, 361365.

(38) Tully, J. Coal Fields of the Counterminous United States. USGS Open-File Report. 1996. http://pubs.usgs.gov/of/1996/of96-092/ other_files/us_coal.pdf.

(39) Ruppert, L. F. Executive Summary- Coal Resource Assessment of Selected Coal Beds and Zones in the Northern and Central Appalachian Basin Coal Regions, Profesional Paper 1625-C, 2000.

(40) Lyons, P. C. Paleoenvironmental and Tectonic Controls in Coalforming Basins of the United States; Introduction and Summary; Geological Society of America, 1986.

(41) Tennessee Valley Authority. Corrective action plan for the TVA Kingston fossil plant ash release. 2009. http://www.tva.gov/kingston/ admin_record/pdf/G/G4.pdf.

(42) Bataille, C. P.; Bowen, G. J. Mapping $87 \mathrm{Sr} / 86 \mathrm{Sr}$ variations in bedrock and water for large scale provenance studies. Chem. Geol. 2012, 304-305, 39-52.

(43) Chesson, L. A.; Tipple, B. J.; Mackey, G. N.; Hynek, S. A.; Fernandez, D. P.; Ehleringer, J. R. Strontium isotopes in tap water from the coterminous USA. Ecosphere 2012, 3.

(44) Mc Arthur, J.; Howarth, R.; Bailey, T. Strontium Isotope Stratigraphy: LOWESS version 3: Best Fit Marine Sr-Isotope curve for 0-509 Ma and accompanying look-up table for deriving numerical age. J. Geol. 2001, 109, 155-170.

(45) Schwarcz, H. P.; Agyei, E. K.; McCmulle, Cc. Boron isotopic fractionation during clay adsorption from sea-water. Earth Planet. Sci. Lett. 1969, 6, 1-\&.

(46) Spivack, A. J.; Edmond, J. M. Boron isotope exchange between seawater and the ocean-crust. Geochim. Cosmochim. Acta 1987, 51, 1033-1043.

(47) Palmer, M. R.; Spivack, A. J.; Edmond, J. M. Temperature and $\mathrm{pH}$ controls over isotopic fractionation during adsorption of boron on marine clay. Geochim. Cosmochim. Acta 1987, 51, 2319-2323.

(48) Spivack, A. J.; Palmer, M. R.; Edmond, J. M. The sedimentary cycle of boron isotopes. Geochim. Cosmochim. Acta 1987, 51, 19391949. 